F 17 肉腫様変化を伴う肺癌のp53遺伝子 異常の検討

広島大学医学部外科学第一講座 1 、

同病理学第二講座 ${ }^{2}$

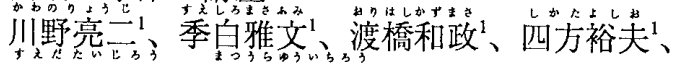
末日秦一郎”松浦雄一郎 ${ }^{1}$

武島幸男、有広光司 ${ }^{2} 、$ 并内康輝 ${ }^{2}$

【目的、対象】原発性肺癌の中には腫場細胞の形 態が紡鍾形となり、肉腫との鑑別が困難な例があ る。こうした肉腫様部分はつよい浸潤能を示す事 が多く、腫瘍細胞の生物学的悪性度の増加と 553 遺 伝子異常が相関する可能性が推测される。そこで 当科で経験した闪腫㥞変化を伴う肺癌 1 例及び関連 施設の3症例について、癌腫部分と肉腫様部分のそ れぞれの成分における免疫組織化学的なp53蛋白の 発現、17p染色体のLoss of heterozygosity (LOH)や p53遺伝子変異の有無について検索した。

【結果、考察】免疫組織化学的なp53蛋白の発現及 びp53遺伝子異常の頻度は、癌腫部分に比較して肉 腫様部分に異常を示す頻度が高く、肉腫様成分に おける生物学的㱏性度の増加は 553 遺伝子異常と相 関する可能性が推测される。

\section{F 19} 非小細胞肺癌のアポトーシスおよび関連する 遺伝子Bcl-2、p53の発現

東北大学加齢医学研究所外科仙台厚生病院外科*

陳炎, 紊藤泰紀, 高橋博人, 佐藤雅美, 佐川元保, 遠藤午顕, 桜田晃, 相川江一, 阿部次郎, 佐藤光春, 橋本博史, 薄田勝男*, 高橋里美*, 藤村栝重文

【目的】非小細胞肺癌におけるアポトーシスおよび アポトーシスに関連する遺伝子Bcl-2、p53の発現を免 疫組織化学的に検討した。

【対象】1991年1月から1995年28月までに切除された 原発性非小細胞肺癌 108 例（扁平上皮癌 55 例, 腺癌 41 例，大細胞癌 12 例）を対象とした。切除材料を 24 時間 ホルマリン固定後パラフィン包埋し，標本艾作製した。 【方法】アポトーシスの発現はApop Tag ${ }^{\mathrm{TM}} \mathrm{Kit}$ 用いて TUNEL法によりアポトーシス細胞を染色した。 Bcl-2、 p53の発現はオトクレーブにより加熱処理した後, 標本 を抗Bcl-2癌遺伝子産物抗体、抗p53蛋白抗体を一次抗 体とし，間接酵素抗体法で観察した。

【結果】アポトーシスの発現は扁平上皮癌35\%(19/55), 腺癌 $27 \%(11 / 41)$, 大細胞癌 $25 \%(3 / 12)$, において観察 された。Bcl-2 は扁平上皮癌 $24 \%(13 / 55)$ ，腺癌 $17 \%$

(7/41)，大細胞癌 $17 \%(2 / 12 ） に, p 53$ は扁平上皮癌 $42 \%(23 / 55)$, 腺癌 $20 \%(8 / 41)$, 大細胞癌 $42 \%$

(5/12)，において陽性所見がみられた。病理病期别 にみるとI期の症例（特に扁平上皮癌）でBcl-2、Apop Tagの陽性率が高い傾向があった。Bcl-2とApop Tagお よびp53とApop Tagには明らかな相関が認められなかっ たが、Bcl-2およびp53が両方陽性の場合にはApop Tag の陽性率が有意に高かった $(\mathrm{p}=0.018)$ 。症例を加え て各陽性率と予後の関係を検討する予定である。
E10 $\begin{aligned} & \text { 肺扁平上皮癌における多剂耐性関連 } \\ & \text { 蛋白(MRP) 遺伝子の発現 }\end{aligned}$

自衛隊横須賀病院 1 、防衛医科大学校第 2 外科 2 、東海 大学医学部第 1 外科 3 、同検診センター 4 、同病理 5

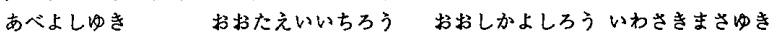
阿部良行 $1,2,5$ 、大田英一郎 2,5 、大鹿芳郎 2,5 , 岩崎正之3、 いのうえひろしかがたとしろう书ぜきういちたなかすすす 并上宏司 $3 、$ 尾形利郎 4 、尾関雄一2、田中 勧2

(目的) 我々は、肺非小細胞癌における Multidrug Resistance-associated Protein (MRP)遺伝子の発現とその臨床 的予後が相関することを発表した(Br J Cancer, 1995）。 今回、MR P 遺伝子発現とその予後が特に有意な相関 を示した肺扁平上皮癌において、MR P 発現と臨床病 理学的所見の関連性を検討した。

(対象と方法) 術前治療を受けていない外科的切除例 の肺扁平上皮癌 40 例を対象とした。MRP遺伝子癹 現はNorthern Blot法にて、強陽性、陽性、陰性の3段 階で判定した。病理学的検討は通常の組織学的方法を 用いて行った。また、予後の解析はKaplan-Meier法と generalized Wilcoxon testにて行った。

(結果) MRP遺伝子発現陽性は 16 例（40\%） で、強陽性例は 13 例であり、分化度別では高 8 、中 6 、低 2 例であった。陽性 16 例中、中枢型 7 、未梢 型 8、不明 1 例であった。また、MR P 関連薬郕使用 例が 20 例で、そのうちMR P 遺伝子発現陽性 9 例は 有意に陰性 11 例より予後不良であった $(\mathrm{p}<0.01)$ 。

(考察) 肺扁平上皮癌におけるMR P 遺伝子発現は臨 床的予後と密接に関連していると考えられた。また、 M R P に対する抗体を用いてその局在を現在検討中で ある。

$モ コ \coprod \begin{aligned} & \text { 肺腺癌におけるc-erb B2の発現とリンパ節転移 } \\ & \text { の関係 }\end{aligned}$

鳥取大学医学部第 2 外科

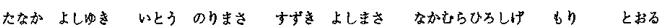
田中宜之、伊藤則正、鈴木喜雅、中村廣繁、森透

【目的】最近、癌遺伝子であるc-erb B2発現上昇は転 移形成と関係するという報告がありc-erb B2 と肺癌の 転移についても興味が持たれているが、肺癌において このような視点で臨床的に検討された報告は少ない。 そこで今回我々は当科で切除した原発性肺腺癌症例に 対しc-erb B2の発現とリンパ節転移との関係を検討す ることを目的とした。【対象と方法】対象は当科で切 除した原発性肺腺癌症例 32 例（男性22例、女性10例 平均年齢62.8歲）。c-erb B2の発現はホルマリン固 定パラフィン切片を抗c-erb B2ポリクローナル抗体を 用いABC法にて免疫組織化学的に検出し、細胞膜およ び細胞質が強く染色されたものを陽性とした。またり ンパ節転移巣に対しても同様の検索を行った。【結 果】32例中8例(25\%)がc-erb B2陽性でありN因子が進 むほどc-erb B2 陽性率が增加する傾向にあった。長期 生存率はerb B2 陽性例が陰性例と比較して若干低いも のの有意差は認めなかった。リンバ節転移巣でのc-erb B2の発現は 32 例中 31 例 $(97 \%)$ が原発巣と同等であっ た。【結論】肺腺癌においてc-erb B2の過剩発現がリ ンパ節転移と関係する事が示唆された。また、リンパ 節転移巣形成に際してc-erb B2は恒常的な発現を示す ことがわかった。 